\title{
Estudio de la fisuración de paneles sándwich de yeso laminado y alma de lana de roca
}

\author{
Study of the cracking of sandwich panels of plasterboard \\ and rockwool
}

\author{
J. A. Alonso(*), E. Reyes(*) y J. C. Gálvez ${ }^{(*)}$
}

Recepción / Received: 10-IV-12

Aceptación / Accepted: 22-XI-12

\section{RESUMEN}

Este artículo presenta el estudio de la rotura de paneles sándwich de yeso laminado y lana de roca bajo solicitaciones de flexo-tracción dentro de su plano. Estos paneles se emplean para conformar tabiques interiores de edificación y con frecuencia se fisuran por flechas excesivas en los forjados. Actualmente no hay modelos de cálculo fiables ni datos experimentales que permitan estudiar este problema. Este trabajo presenta los resultados de una campaña experimental encaminada a caracterizar el comportamiento en rotura de los paneles sándwich y de sus componentes individuales. Además, se presenta un modelo cohesivo con fisura embebida que permite simular el comportamiento en rotura del panel sándwich conjunto. Por último se presentan los resultados de los ensayos de fractura en modo mixto (tracción/cortante) de paneles comerciales y se reproduce su comportamiento con el modelo cohesivo propuesto, obteniéndose un buen ajuste.

Palabras clave: panel sándwich; yeso; fisuración; elementos finitos; simulación numérica.

\begin{abstract}
This paper presents the study of plasterboard and rockwool sandwich panels cracking under flexural loading. These panels are usually used to perform interior partition walls and they frequently show cracking pathology due to excessive deflexion of the slabs. There are currently no reliable simulation models and experimental data for the study of this problem. This paper presents the results of an experimental campaign aimed to characterize the fracture behaviour of sandwich panels and their individual components. In addition, the paper presents a cohesive model with embedded crack to simulate the fracture behaviour of the panel. Finally we present the results of tests for mixed mode fracture (tensile / shear) commercial panels and their behaviour is reproduced with the cohesive model proposed, yielding a good fit.
\end{abstract}

Keywords: sandwich panel; plasterboard; fracture; finite element; numerical modeling.

(*) Universidad Politécnica de Madrid (Madrid, España). 


\section{INTRODUCCIÓN}

La placa de yeso laminado es un material que se emplea desde hace varias décadas en la ejecución de particiones verticales interiores en edificación. En Europa se estima una producción anual aproximada de 1.000 millones de $\mathrm{m}^{2}$, de los cuales aproximadamente el $75 \%$, se destina a esta aplicación (1). Su uso mayoritario es en edificación no residencial y en reformas, y se estima que el consumo de España es de 30 millones de $\mathrm{m}^{2}$, de los que un $70 \%$ se usa en la construcción de tabiques y trasdosado de muros (1). Otra de las aplicaciones fundamentales de la placa de yeso laminado es la realización de falsos techos o como componente de paneles sándwich para la formación de cubiertas. Este último uso justifica que las características mecánicas más estudiadas de este material estén relacionadas con la flexión fuera del plano de sus caras (véase (2) entre otros estudios).

La industrialización de la construcción hace que el uso de este material esté en expansión, debido a la gran ventaja de rapidez de ejecución que aporta, así como otras inherentes a los procesos de construcción en seco. Además, el cumplimiento de los valores límites de aislamiento acústico frente al ruido aéreo establecidos en el Código Técnico de la Edificación español y, más en concreto del DB - HR: "Protección frente al ruido" (3), de reciente aparición, contempla emplear este tipo de soluciones, en detrimento de las fábricas tradicionales (4), denominando a este tipo de tabiquería como: "particiones interiores verticales de entramado autoportante" (véase solución tipo 3 del apdo. 4.4.3 en (3)).

La distinta rigidez que presentan los paneles de yeso laminado y los elementos estructurales en los que se apoya a través de perfiles metálicos, dificulta el que los puedan acompañar en sus movimientos como puede ocurrir frecuentemente por las deformaciones que experimentan los forjados. De esta forma pueden aparecer fisuras debidas, por ejemplo, a deformaciones diferidas de los forjados, o a asientos diferenciales. Lo común en este tipo de fallos es la formación de una o un número discreto de fisuras de un tamaño considerable, lo cual es característica intrínseca de un problema de fisuración por tracción y cortante (5-7).

No existe normativa oficial en Europa para determinar la viabilidad del uso de paneles de yeso laminado como particiones y son escasos los estudios, tanto experimentales como numéricos, realizados sobre el comportamiento de estos elementos. Algunos trabajos recientes han estudiado el comportamiento mecánico-resistente de elementos no estructurales de yeso en su plano desde el punto de vista experimental o numérico (8-10). Sin embargo, el tema necesita más investigación, ya que, como se ha comentado anteriormente, su uso es muy frecuente en elementos no estructurales de partición vertical. El

\section{INTRODUCTION}

Plasterboard panels have been used for internal vertical divisions in building for several decades. The estimated production in Europe is around 1000 millions $m^{2}$, of which approximately $75 \%$ goes to this application (1). The main use is in non-residential buildings and building refurbishment. It is estimated that consumption of Spain is 30 million $\mathrm{m}^{2}$, of which $70 \%$ is used in the construction of walls and panelling plasterboard (1). Other fundamental applications of laminated plasterboard involve false ceilings and use as a component of sandwich panels for roofing. This last use justifies deeper study of the mechanical properties related with out-of-plane bending (see (2) among other papers).

The industrialisation of construction has led to such a use of the material being in expansion: this is due to the significant advantage of velocity of execution that contributes, as well as others, to the processes related with dry construction. In addition, compliance with acoustic insulation against airborne noise limits, prescribed by the Spanish Technical Code for Building, and more specifically the new CTE-DB-HR (protection against noise)(3), contemplates the use of this solution rather than traditional masonry (4). Such a type of partitioning may be considered as the interior vertical partitions of a self-supporting frame (see solution type 3, section 4.4 .3 in (3)).

The different degrees of stiffness between plasterboard panels and structural elements, supported through metallic profiles, hinder the frequent movement that may occur because of a deflection of the slabs. Hence, cracks may appear due to either deferred deformations of the slabs or differential settlements. Commonly, in such a type of failure one or a certain number of cracks of a considerable size appear (this is a typical problem of tensile and shear cracking) (5-7).

There are no official standards in the European Union (EU) to determine the feasibility of the use of plasterboard panels as internal walls. Experimental and numerical studies focussed on the behaviour of these elements are scarce. Some recent works have studied the strength and mechanical in-plane properties of non-structural gypsum elements from a numerical or experimental point of view (8-10). For this reason, the field requires more extensive research, given the common use of non-structural elements such as internal vertical walling. Consequently, this work contributes to reducing this gap in knowledge and 
presente artículo pretende contribuir a reducir esta laguna en el conocimiento así como al desarrollo de herramientas de cálculo que faciliten el estudio de la fisuración de este tipo de particiones interiores.

Puesto que no existen en la actualidad datos experimentales para poder evaluar el comportamiento en fractura de la placa de yeso laminado, ni del panel sándwich de yeso laminado con lana de roca, en este trabajo se ha diseñado una campaña de ensayos con el objetivo de obtener las propiedades de fractura, tanto del material compuesto como las de cada uno de sus componentes. Estos datos del material, hasta ahora inexistentes, son necesarios para los modelos de cálculo que permitan simular el comportamiento en fractura de este material. De esta forma será posible limitar la flecha de forjados para evitar la fisuración de estos paneles.

Este trabajo presenta un modelo de cálculo de fisura cohesiva, incorporada a un elemento finito con fisura embebida, que utiliza como entrada los parámetros obtenidos de la experimentación. Este modelo de fisura embebida ha sido utilizado por los autores con éxito en la simulación numérica de la fractura de distintos materiales cuasi frágiles (5-7), y en este estudio se ha utilizado para simular el comportamiento en fractura del panel de yeso laminado, obteniendo una buena aproximación de los resultados experimentales. El trabajo incluye el estudio de la propagación de grietas bajo solicitaciones de tipo mixto (modos I y II de fractura).

\section{CAMPAÑA EXPERIMENTAL}

La campaña experimental llevada a cabo en este trabajo se diseñó con el fin de obtener las características mecánicas relacionadas con la fractura del panel sándwich de placas de yeso laminado y lana de roca: resistencia a tracción $\left(\mathrm{f}_{\mathrm{t}}\right)$, módulo de elasticidad $(\mathrm{E})$ y energía específica de fractura $\left(\mathrm{G}_{\mathrm{F}}\right)$.

El panel sándwich está formado por varios materiales de características mecánicas y resistentes muy distintas. Para estudiar la influencia que tiene cada componente en las características del material compuesto, se realizaron ensayos de cada uno de los materiales componentes del panel sándwich de forma independiente. De esta forma se ensayó por un lado el yeso laminado, compuesto a su vez por yeso y papel, ensayados también cada uno por separado, y por otro la lana de roca.

También se realizaron ensayos de fractura del mismo panel en sentido transversal y longitudinal, así como ensayos de compresión de lana de roca, en estas dos direcciones, realizados para comprobar la isotropía del material. supplies modelling tools that facilitate the study of the cracking of this type of interior partitions.

Given that currently there is not enough experimental data to evaluate the in-plane bending failure of plasterboard and sandwich panels of plasterboard and rockwool, this work performs an experimental programme to obtain the fracture properties, of both the composite panel and each of its components. The data associated with the material, until now unavailable, are needed for the calculation models that simulate fracture behaviour. Acquisition of such data will make it possible to limit slab flexure and then prevent the cracking of the panels.

This paper presents a cohesive crack model, implemented into a finite element with an embedded crack, which uses as an input the parameters obtained from the experimentation. The embedded crack model, which has been used by authors in the numerical simulation of the fracture of quasi-brittles materials (5-7), is implemented in this work to simulate the fracture behaviour of plasterboard panels, with the experimental results providing a good fit. In addition to this, the paper also includes the study of crack growing under mixed mode loading (type modes I and II).

\section{EXPERIMENTAL PROGRAMME}

The experimental programme was designed for obtaining the mechanical properties related to the fracture of sandwich panels of plasterboard and rockwool: tensile strength $\left(f_{t}\right)$, Young's modulus $(E)$ and specific fracture energy $\left(G_{F}\right)$.

Sandwich panels include several materials of significantly different mechanical and resistant properties. In order to study the influence that each component has on the mechanical behaviour composite material, tests of each component of the sandwich panel materials were carried out independently. This involved both a plasterboard panel, composed of gypsum and paper (also tested separately), and rockwool.

Fracture tests of the same panel in longitudinal and transverse direction were also performed, as well as compression of rockwool (carried out to check the isotropy of the material). 


\subsection{Materiales}

La Figura 1 muestra un esquema de los paneles estudiados. Están formados por dos caras de placa de yeso laminado, encoladas mediante colas de poliuretano aplicadas en frío a un alma de lana de roca de $170 \mathrm{~kg} / \mathrm{m}^{3}$ de densidad.

\subsection{Materials}

Figure 1 shows a sketch of the studied panels. They are formed by two sides of plasterboard and joined by using polyurethane glues cold applied to a core of $170 \mathrm{~kg} / \mathrm{m}^{3}$ density rockwool.

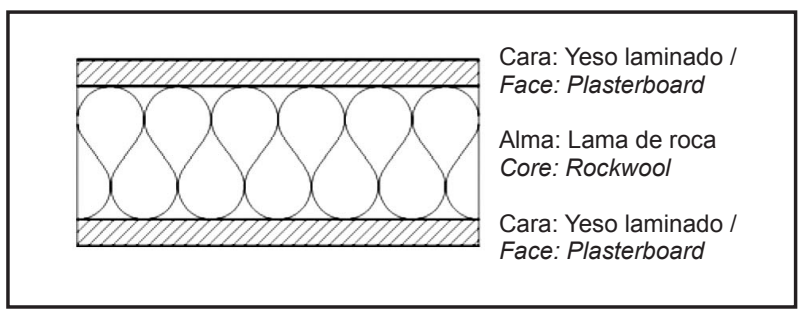

Figure 1. Esquema de panel sándwich con caras de yeso laminado y alma de lana de roca.

Figure 1. Sketch of the sandwich panel with plasterboard surfaces and rock wool core.

Las paneles necesarios para realizar los ensayos, se obtuvieron a partir de paneles sándwich de placa de yeso laminado y lana de roca comerciales. Los tipos y dimensiones de los paneles se reflejan en la Tabla 1.

Las placas de yeso laminado y la lana de roca empleadas en la fabricación de los paneles, cumplen con las especificaciones fijadas en las norma UNE EN 520 (11) y UNE EN 13.162 (12), respectivamente.
The tests were performed with specimens obtained from commercial sandwich panels of plasterboard and rockwool. The types and dimensions of the specimens are shown in Table 1.

The sandwich panels of plasterboard and rockwool used for performing the specimens comply with the specifications laid down in the standard UNE EN 520 (11) and UNE EN 13.162 (12), respectively.

Tabla 1 / Table 1

Dimensiones y tipos de los paneles estudiados.

Type and dimensions of the plasterboard sandwich panels.

\begin{tabular}{|c|c|c|}
\hline $\begin{array}{l}\text { Tipo / Type } \\
\text { e-E-e }\end{array}$ & $\begin{array}{l}\text { Caras: yeso laminado I } \\
\text { Surface: plasterboard }\end{array}$ & $\begin{array}{c}\text { Alma: lana roca I } \\
\text { Core: rock-wool }\end{array}$ \\
\hline \multirow{4}{*}{$\begin{array}{l}10-50-10 \\
10-60-10 \\
12-50-12 \\
12-60-12\end{array}$} & 10 & 50 \\
\hline & 10 & 60 \\
\hline & 12 & 50 \\
\hline & 12 & 60 \\
\hline
\end{tabular}

$\mathrm{e}=$ espesor de la placa de yeso laminado $(\mathrm{mm}) /$ thickness of plasterboard surface $(\mathrm{mm})$

$\mathrm{E}=$ espesor de la lana de roca $(\mathrm{mm}) /$ thickness of the rock-wool core $(\mathrm{mm})$.

\subsection{Probetas}

De acuerdo con la campaña experimental diseñada, las probetas necesarias para realizar los ensayos se obtuvieron a partir de los paneles sándwich comerciales recibidos. Con objeto de garantizar la uniformidad de los paneles utilizados en los ensayos, la placa de yeso laminado y lana de roca eran de la misma partida de material.

Las probetas de yeso laminado se obtuvieron a partir de placas de la misma partida de material empleada para fabricar los paneles sándwich. Las de lana de roca se

\subsection{Specimens}

According to the experimental programme, specimens needed for performing the tests were obtained from received commercial sandwich panels. To guarantee the uniformity of the panels used in the tests, plasterboard plate and rockwool were from the same item of sandwich panels.

Plasterboard specimens were obtained from plates of the same material used to manufacture sandwich panels. The rockwool specimens were prepared by removing the 
prepararon eliminando las caras del panel sándwich. Para estudiar las características del yeso solo se prepararon probetas eliminando el papel de la placa de yeso laminado, con una rectificadora. Por último, el papel se obtuvo sometiendo a compresión la placa de yeso laminado, para eliminar prácticamente todo el yeso de la misma, y acabando el proceso de eliminación a mano, para quitar los restos de yeso que quedaban todavía adheridos al papel. Se comprobó visualmente que el papel no había sufrido daños.

\subsection{Descripción de los ensayos}

\subsubsection{Energía específica de fractura}

La energía específica de fractura, $G_{F}$ del panel y sus componentes: yeso, yeso laminado y lana de roca, se obtuvo por medio de ensayos de fractura en modo I, realizando un ensayo de flexión en tres puntos. Únicamente en el caso del papel que forma parte de la placa de yeso laminado, se realizó un ensayo de fractura en modo III, debido a la imposibilidad de realizar el anterior. También, y con el fin de comprobar la isotropía transversal del panel, se realizaron ensayos de fractura en dos direcciones perpendiculares.

Las medidas de las probetas de los paneles, Tabla 2, variaban en función de su espesor, de tal manera que su canto fuera igual a su espesor nominal, y la longitud cuatro veces y media su canto. Posteriormente, las probetas destinadas a medir la energía de fractura, se entallaron por su centro hasta la mitad de su canto.

El ensayo de flexión en tres puntos se realizó siguiendo la recomendación RILEM 50-FMC (1986), para la medida de la energía de fractura (13). Las dimensiones parametrizadas en función del espesor, $D$, de la probeta, así como el esquema del ensayo se indican en la Figura 2.

La carga se aplicó con el actuador sobre un rodillo de acero de $10 \mathrm{~mm}$ de diámetro. La probeta se apoyaba en sendos rodillos de $10 \mathrm{~mm}$ de diámetro. Con el fin de evitar el aplastamiento local de la probeta en la zona de apoyo del rodillo se adhirieron unas placas de aluminio de $70 \times 20 \times 4 \mathrm{~mm}$ a la probeta en dicha zona, sobre las que aplicaba el rodillo la carga. Los rodillos se apoyaban a su vez sobre una articulación anti-torsión. Finalmente, el conjunto descansaba sobre una guía lineal de rodillos que permitía el deslizamiento sobre el plano de apoyo, con un rozamiento virtualmente nulo. De este modo, los apoyos eran articulaciones que permitían el giro en todas las direcciones y el desplazamiento horizontal. El plano de apoyo estaba materializado por una viga metálica muy rígida, atornillada a la parte inferior del bastidor de la máquina de ensayos. La Figura 3 muestra una foto del dispositivo de ensayo. sides of the sandwich panel. To study the characteristics of plasterboard alone, specimens were prepared by eliminating the laminated paper of plasterboard with a grinder. Finally, the paper was obtained by compression of the plasterboard plate, for removing the gypsum, with the process of elimination being ended by hand (removing the remains of gypsum that were still attached to the paper). A visual inspection found that the paper was undamaged.

\subsection{Experimental procedure}

\subsubsection{Specific fracture energy}

Specific fracture energy, $G_{F}$, of the sandwich panel and its components (gypsum, plasterboard and rockwool) was obtained through three-point bending (TPB) fracture tests. Only in the case of the paper of the plasterboard was a test of fracture in mode III performed, with the reason being due to the difficulties in carrying out the TPB fracture test. Moreover, the fracture tests were performed with specimens obtained from two perpendicular directions of the plasterboard and sandwich panel, with the purpose being verification of the transverse isotropy of the material.

Table 2 shows the dimensions of the specimens which depend on the specimen thickness. Depth is equal to thickness and length four times that of the thickness. Subsequently, fracture specimens were notched in the centre of the span to the middle of the thickness.

TPB fracture tests were performed by following the RILEM 50-FMC (RILEM 50-FMC Committee Fracture Mechanics of Concrete) (13). Figure 2 shows the test arrangement and parameterised dimensions, as a function of depth $D$, of the specimen.

Load was applied by means of a $10 \mathrm{~mm}$ steel roller. The specimen was rested on two $10 \mathrm{~mm}$ steel cylinders. To avoid local crushing of the specimen in the zone of the roller supports, $70 \times 20 \times 4 \mathrm{~mm}$ aluminium plates were inserted between the roller and specimen. The beams were rested on two rigid steel cylinders laid on two ground supports, which allowed free rotation out of the plane of the beam and guaranteed negligible friction rolling in the longitudinal direction of the beam. The support plane was materialised by a highly rigid metal beam screwed to the lower part of the frame of the testing machine. A photo of the testing device is shown in Figure 3. 


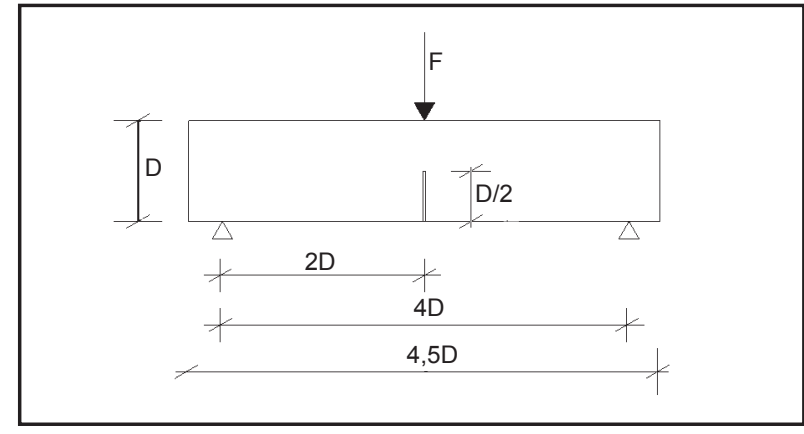

Figura 2. Esquema de ensayo, geometría y dimensiones de las probetas de fractura.

Figure 2. Testing arrangement, geometry and dimensions of the fracture specimens.

Durante el ensayo se registró el desplazamiento vertical del punto de aplicación de la carga, la apertura de la boca de entalla y la carga aplicada. Durante el ensayo, la máquina controlaba el desplazamiento del punto de aplicación de la carga a una velocidad constante de $0,03 \mathrm{~mm} / \mathrm{min}$. Tras el ensayo se pesó cada probeta y se midió la profundidad de la entalla en el interior de la probeta.

En el caso del papel que recubría el yeso, la energía de específica de fractura (rasgado) se obtuvo mediante un ensayo de fractura en Modo III, debido a las dificultades que entrañaba el obtener la energía específica de fractura del papel con ensayos de flexión en tres puntos.

En este caso la probeta estaba seccionada a lo largo de su longitud, dividiéndola en dos zonas: una en la que se mantenía la sección inicial de la probeta (zona A en la Figura 4a), y otra en la que la sección se dividía en dos partes iguales en el sentido de su eje longitudinal (zona B en la Figura 4a). Después cada parte de la zona $B$ se unía a las dos mordazas de la máquina de ensayo, tal como se muestra en la Figura 4b.

Previamente a la aplicación de la carga de tracción, se comprobó que la distancia desde el punto de unión de las dos mitades a las mordazas fuese igual (punto $M$ de la Figura 4b). La tracción fue aplicada, sobre cada parte de la probeta, por medio del desplazamiento del actuador de la máquina, a una velocidad de ascenso constante de $0,02 \mathrm{~mm} / \mathrm{s}$ hasta el final del ensayo. La energía específica de fractura se obtuvo dividiendo el trabajo realizado en la rotura de la probeta por el área de la superficie de rasgado.

Las variables registradas durante el ensayo fueron la fuerza y el desplazamiento del actuador. Así mismo, se midió con un calibre la longitud de la grieta producida y el espesor de la probeta de papel. Este último se midió en tres puntos de la probeta, tal y como se indica en la Figura 5.

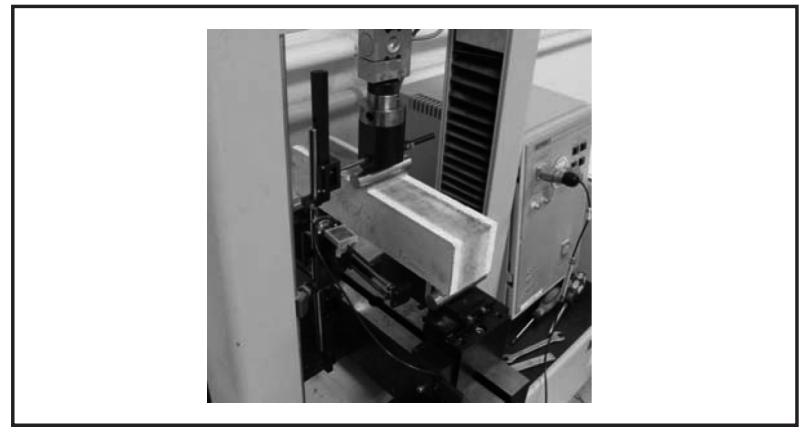

Figura 3. Ensayo de flexion en tres puntos del panel sándwich de yeso laminado y lana de roca.

Figure 3. Three point bending test of a sandwich panel with plasterboard surfaces and rock wool core.

During the test, applied load, load-point displacement and crack mouth opening displacement (CMOD) were continuously recorded. The tests were performed in load-point displacement control, at a rate of $0.03 \mathrm{~mm} / \mathrm{min}$. After testing, each specimen was weighed and the depth of the notch measured.

In the case of the paper that covered gypsum, specific fracture energy was obtained by a mode III (tearing) fracture test because of the difficulties involved in obtaining specific fracture energy of paper with TPB tests.

In this case the specimen was sectioned along its length, dividing it into two zones: one which remained the initial section of the test specimen (area $A$ in Figure 4a), and another in which the section was divided in two equal parts in the sense of its longitudinal axis (area B in Figure 4a). Then each part of zone $B$ joined the two jaws of the test machine, as shown in Figure $4 b$.

Prior to the application of the traction load, it was found that the distance from the point of union of the two halves to the jaws should be equal (point M of Figure 4b). Traction was applied on each part of the test specimen through the displacement of the actuator of the machine, at a rate of $0.02 \mathrm{~mm} / \mathrm{s}$ until the end of the test. The specific energy of fracture was obtained by dividing the work done in the rupture of the specimen for the area of the surface of tearing.

During the test, applied load and load-point displacement were continuously recorded. Likewise, the crack length and the thickness of the paper specimen were also gauged. The latter was measured at three points on the test specimen, as shown in Figure 5. 


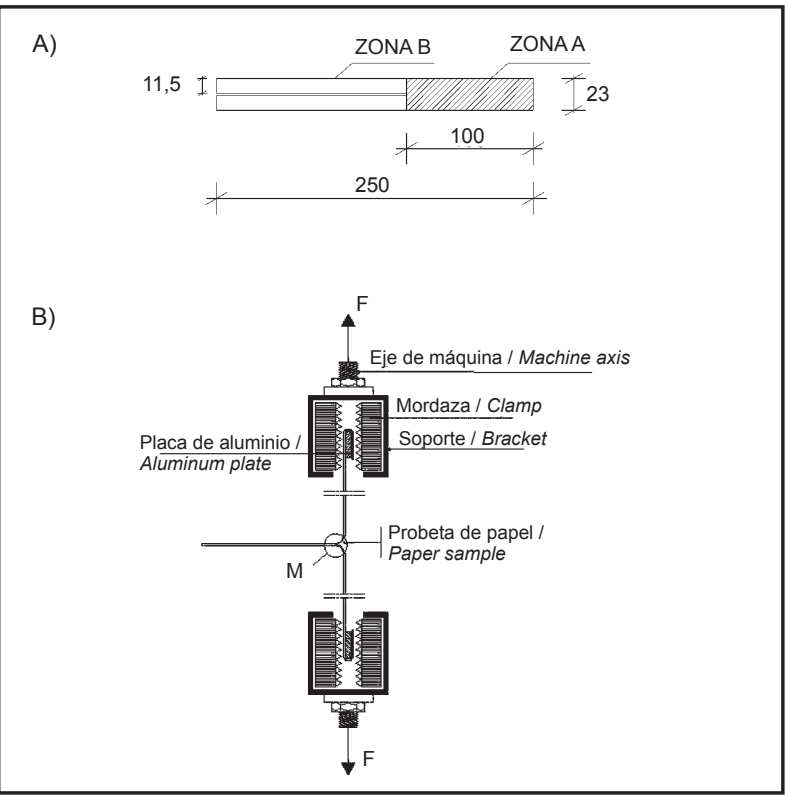

Figura 4. Ensayo de fractura del papel en modo III:

a) esquema de la probeta utilizada, b) esquema del dispositivo experimental.

Figure 4. Fracture of paper under Mode III loading:

a) Sketch of the specimen, b) Sketch of the experimental arrangement.

\subsubsection{Ensayo de tracción}

Las placas de yeso laminado y el papel de la misma, se sometieron a ensayo de tracción, con el fin de obtener su resistencia a tracción y módulo de elasticidad. La geometría y dimensiones de las probetas de yeso laminado pueden verse en la Figura 6. La deformación se midió con extensómetro resistivo.

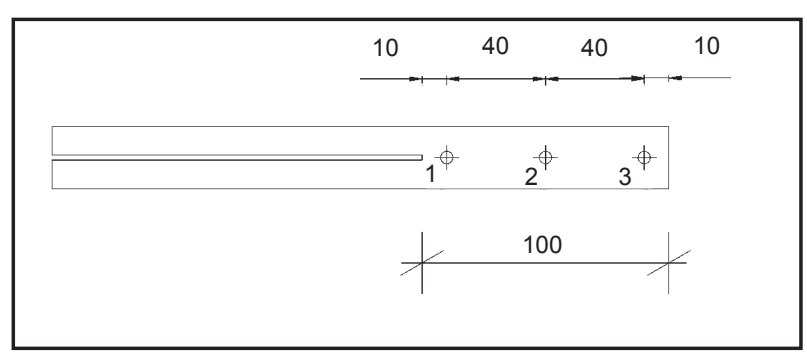

Figura 5. Puntos de medida del espesor en las probetas de papel.

Figure 5. Points for thickness measuring in the paper specimen.

\subsubsection{Tensile strength}

The tensile strength and the Young's modulus of the plasterboard panels and the paper were measured. Figure 6 shows the geometry and dimensions of the plasterboard panel specimens. The strain was measured with a resistive extensometer.

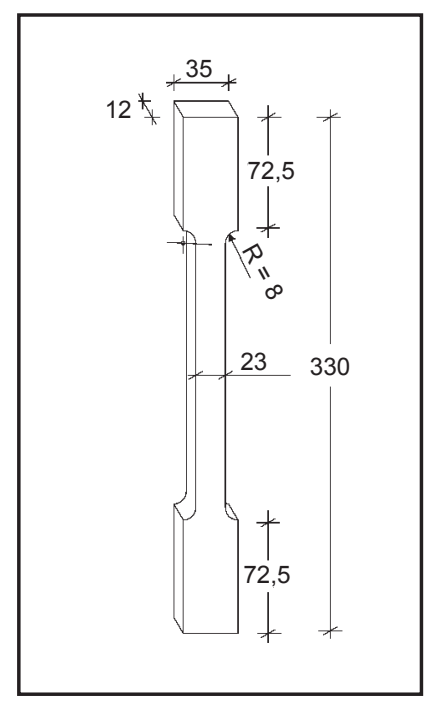

Figura 6. Dimensiones de la probeta de yeso laminado para el ensayo de tracción. Figure 6. Dimensions of the plasterboard specimen tensile test. 
La tracción fue aplicada por medio del desplazamiento del actuador de la máquina, a una velocidad de ascenso constante de 0,02 mm/s hasta el final del ensayo. Durante el ensayo se registró la fuerza y el desplazamiento del extensómetro. Al finalizar el ensayo se midieron, con un calibre, el espesor y ancho en dos puntos de la probeta, alrededor de la zona de fractura.

\subsubsection{Ensayo de flexión}

En el caso de los paneles sándwich, las dificultades que planteaba la mecanización de las probetas de tracción y su fijación a las mordazas de la máquina de ensayo por su gran espesor, obligó a obtener el módulo de elasticidad, a partir de ensayos de flexión aplicando las fórmulas clásicas de la resistencia de materiales. Las probetas ensayadas tenían las dimensiones recogidas en la Tabla 2, pero no estaban entalladas. El proceso de ensayo fue análogo al descrito en 2.3.1.
Tensile testing was carried out by means of a force actuator at velocity ratio of $0.02 \mathrm{~mm} / \mathrm{s}$ until the end of testing. During the test, applied load and extensometer opening displacement were continuously recorded. After testing, the thickness and width on two points of the specimen were measured.

\subsubsection{Bending tests}

In the case of the sandwich panels, due to the difficulties associated with the machining of the tensile specimens and their fitting to the jaws, caused by their large thickness, the Young's modulus was measured with the bending tests and based on the strength of materials theory. Table 2 shows the dimensions of the specimens; in this case they were not notched. The procedure is equivalent to that described in 2.3.1.

Tabla 2 / Table 2

Ensayo de flexión en tres puntos: medidas de las probetas. Dimensions of the specimens for fracture testing.

\begin{tabular}{|c|c|c|c|c|}
\hline \multirow{2}{*}{\multicolumn{2}{|c|}{ Materiales / Materials }} & \multicolumn{3}{|c|}{ MEDIDAS / Dimension (mm) } \\
\hline & & \multirow{2}{*}{$\begin{array}{c}\begin{array}{c}\text { Longitud / } \\
\text { Length (L) }\end{array} \\
315 \\
\end{array}$} & \multirow{2}{*}{$\begin{array}{c}\begin{array}{c}\text { Ancho I } \\
\text { Thickness (B) }\end{array} \\
70 \\
\end{array}$} & \multirow{2}{*}{$\begin{array}{c}\begin{array}{c}\text { Canto / } \\
\text { Depth (D) }\end{array} \\
70\end{array}$} \\
\hline \multirow{4}{*}{$\begin{array}{l}\text { Panel Sándwich / } \\
\text { Sandwich Panel }\end{array}$} & $10-50-10$ & & & \\
\hline & $10-60-10$ & 360 & 80 & 80 \\
\hline & $12-50-12$ & 333 & 74 & 74 \\
\hline & $12-60-12$ & 378 & 84 & 84 \\
\hline \multicolumn{2}{|c|}{ Yeso laminado / Plasterboard } & 337.5 & 75 & 12 \\
\hline \multicolumn{2}{|c|}{ Lana Roca / rock wool } & 337.5 & 75 & 50 \\
\hline
\end{tabular}

\subsubsection{Ensayo de compresión centrada}

Con el fin de obtener el módulo de elasticidad de la lana de roca, y ante las dificultades de su mecanización y fijación a las mordazas en un ensayo de tracción, se realizaron ensayos de compresión. Las dimensiones de las probetas fueron de 60×60×120 mm. La deformación se midió con extensómetro resistivo.

La compresión fue aplicada por medio del desplazamiento del actuador de la máquina, a una velocidad constante de $0,02 \mathrm{~mm} / \mathrm{s}$ hasta el final del ensayo. Durante el ensayo se registró la fuerza y el desplazamiento del extensómetro. Antes del ensayo se midió, con un calibre, la altura, espesor y ancho de la probeta.

\subsubsection{Ensayo de flexión asimétrica}

Con objeto de estudiar el comportamiento del material bajo solicitaciones de tracción y cortante se realizaron ensayos de flexión asimétrica. Durante la experimentación la carga se aplicaba en tres puntos con la entalla situada

\subsubsection{Compression test}

In the case of rockwool, due to difficulties in machining and fixing it to jaws, a compression test was performed, with $60 \times 60 \times 120 \mathrm{~mm}$ being the dimension of the specimens. Strain was measured with a resistive extensometer.

Compression testing was carried out by means of a force actuator at velocity ratio of $0.02 \mathrm{~mm} / \mathrm{s}$ until the end of testing. During the test, applied load and the extensometer opening displacement were continuously recorded. Before testing, the height, thickness and width of the specimen were measured.

\subsubsection{Non-symmetric bending test}

Non-symmetric bending tests were carried out to study the behaviour of the material under tensile and tangential loading. The test was performed by a TPB setup, with the notch of the specimen in an asymmetric place. The 
en una posición asimétrica, para conseguir la rotura de la probeta bajo tensiones normales y tangenciales. El canto de las probetas de panel y lana de roca era igual al espesor en cada uno de los casos estudiados. Las dimensiones parametrizadas en función del espesor, $D$, de la probeta se indican en la Figura 7. En este trabajo se ensayaron dos probetas por cada uno de los cuatro espesores de panel. depth and thickness of the specimens were equal. The parameterised $D$ dimensions of the specimens are shown by Figure 7. Two specimens of each of the four thicknesses of the panels were tested.

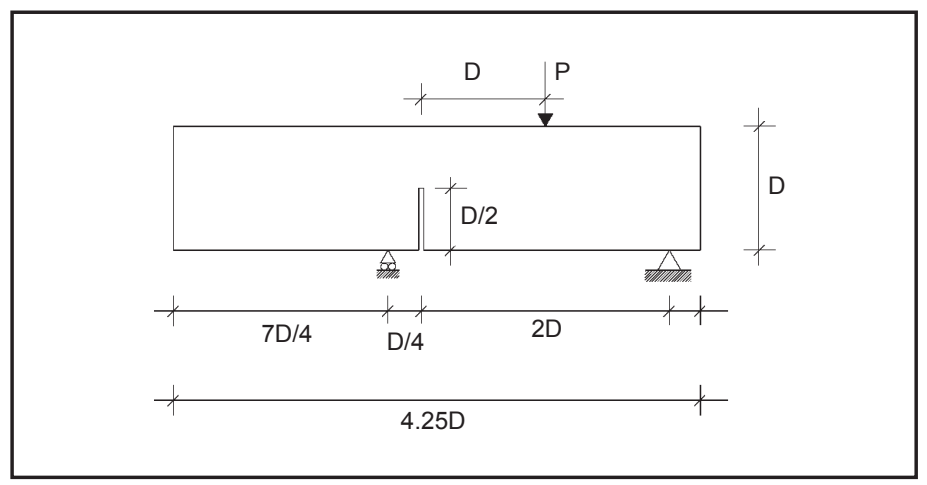

Figura 7. Esquema de ensayo, geometría y dimensiones de las probetas de fractura en modo mixto.

Figure 7. Testing arrangement, geometry and dimensions of the fracture specimens under mixed mode loading conditions.

La forma de aplicación de la carga, así como la disposición de los rodillos de apoyo, es análoga a lo descrito en 2.3.1. Los ensayos se realizaron a una velocidad de $0,04 \mathrm{~mm} /$ min del actuador. Las probetas se instrumentaron con un extensómetro resistivo para medir la apertura de la boca de la entalla (CMOD).

\subsection{Equipos e instrumentación}

Todos los ensayos se realizaron con una máquina servo hidráulica universal de ensayos mecánicos marca SERVOSIS, modelo ME 405/1, de 1.000 kN de capacidad. Para cada experimento se adaptaron el utillaje y los transductores apropiados. La máquina de ensayos está dotada de un sistema de control electrónico que puede recibir la señal analógica de cuatro transductores independientes. Dos de estos transductores pertenecen a la configuración básica de la máquina, y se utilizan para medir la carga aplicada y el desplazamiento del actuador. Se utilizaron además dos extensómetros resistivos HBM DA1 de $\pm 2,5 \mathrm{~mm}$ de recorrido (extensómetro tipo clip), en distintas disposiciones según el tipo de ensayo, para medir desplazamientos y abertura de la boca de la entalla (CMOD).

\section{RESULTADOS EXPERIMENTALES}

La Tabla 3 muestra los resultados experimentales obtenidos de $G_{F}, f_{t}$ y $E$ para cada uno de los constituyentes del panel sándwich. La Tabla 4 muestra los valores medios obtenidos para cada tipo de panel sándwich a partir de los resultados de seis probetas. La Figura 8 muestra las curvas carga-desplazamiento del punto de aplicación de la
The test setup is described in 2.3.1. It was carried out by means of a force actuator at velocity ratio of $0.04 \mathrm{~mm} / \mathrm{min}$. CMOD was measured with a resistive extensometer.

\subsection{Testing equipment}

The tests were carried out with the universal mechanical testing machine SERVOSIS, ME 405 / 1 model, with 1000 $k N$ of loading capacity. Appropriate devices and extensometers were used for each testing procedure. The testing machine is equipped with an electronic control system that can receive the analogical signal from four separate transducers. Two of these transducers belong to the basic configuration of the machine, and are used to measure the applied load and the displacement of the actuator. In addition, two resistive extensometers $H B M D A 1$ with $\pm 2.5 \mathrm{~mm} / \mathrm{min}$. of travel (extensometer type clip), with different arrangements according to the type of test, were used to measure displacements and the opening of the mouth of the notch (CMOD).

\section{EXPERIMENTAL RESULTS}

Table 3 shows the experimental results of $G_{F}, f_{t}$ and $E$ for each of the constituent parts of the sandwich panel. Table 4 shows the average values obtained for each type of panel sandwich from the results of six specimens. Figure 8 shows the curves load-displacement of the point of application of the load corresponding to the fracture 
carga correspondientes a los ensayos de medida de energía de fractura de los paneles sándwich. Como se puede observar los ensayos son estables y repetitivos. energy tests of sandwich panels. The tests are stable and repetitive.

Tabla 3 / Table 3

Valores experimentales de las propiedades mecánicas de los constituyentes del panel sándwich. Mechanical properties of the sandwich panel constituent materials.

\begin{tabular}{|c|c|c|c|}
\hline \multirow{2}{*}{ Material / Materials } & $G_{F}(\mathrm{~N} / \mathrm{m})$ & $\boldsymbol{f}_{t}(\mathrm{MPa})$ & $\boldsymbol{E}(\mathrm{MPa})$ \\
\cline { 2 - 4 } & Media $(\sigma) /$ Mean $(\sigma)$ & Media $(\sigma) /$ Mean $(\sigma)$ & $1.55(0.22)$ \\
\hline Yeso laminado / Plasterboard & $463(33.50)$ & $0.085(0.01)$ & $348(64.1)$ \\
\hline Lana Roca / Rockwool & $157(31.60)$ & $0.50(0.26)$ & $98.6(26.6)$ \\
\hline Yeso / Gypsum & $17(5.10)$ & $10.28(0.60)$ & - \\
\hline Papel / Paper & $1.025(73.60)$ & $27.7(11.3)$ \\
\hline
\end{tabular}

$G_{F}$ energía de fractura / specific fracture energy.

$f:$ resistencia a tracción / tensile strength.

E: módulo de elasticidad / Young's modulus.

Tabla 4 / Table 4

Valores experimentales de las propiedades mecánicas de los paneles sándwich. Mechanical properties of the sandwich panels.

\begin{tabular}{|c|c|c|c|}
\hline \multirow{2}{*}{$\begin{array}{c}\text { Tipo } / \text { Type } \\
\text { e-E-e }\end{array}$} & $G_{F}(\mathbf{N} / \mathbf{m})$ & $\boldsymbol{f}_{\boldsymbol{t}}(\mathrm{MPa})$ & $E(\mathrm{MPa})$ \\
\cline { 2 - 4 } & Media $(\boldsymbol{\sigma}) /$ Mean $(\boldsymbol{\sigma})$ & Media $(\boldsymbol{\sigma}) /$ Mean $(\boldsymbol{\sigma})$ & Media $(\boldsymbol{\sigma}) /$ Mean $(\boldsymbol{\sigma})$ \\
\hline $10-50-10$ & $437(80.01)$ & $1.08(0.19)$ & $140(9.20)$ \\
\hline $10-60-10$ & $490(119.5)$ & $0.98(0.14)$ & $113(13.6)$ \\
\hline $12-50-12$ & $463(128.5)$ & $1.13(0.24)$ & $126(11.4)$ \\
\hline $12-60-12$ & $548(118.3)$ & $1.01(0.09)$ & $107(20.1)$ \\
\hline
\end{tabular}

$e=$ espesor de la placa de yeso laminado $(\mathrm{mm}) /$ thickness of plasterboard surface $(\mathrm{mm})$.

$\mathrm{E}=$ espesor de la lana de roca $(\mathrm{mm}) /$ thickness of the rock-wool core $(\mathrm{mm})$.

$G_{F}$. energía de fractura / specific fracture energy.

$f t:$ resistencia a tracción / tensile strength.

E: módulo de elasticidad / Young's modulus.

La Tabla 5 muestra los valores obtenidos en los ensayos de fractura de probetas del mismo panel sándwich cortadas en la dirección longitudinal y transversal, realizados para comprobar la posible anisotropía del material. La Tabla 6 muestra análogos resultados para la lana de roca que constituye el alma de los paneles sándwich.
Table 5 shows the values obtained in the fracture energy tests of specimens of the same panel sandwich cut into the longitudinal and transversal directions to check possible anisotropy of the material. Table 6 shows similar results for the rockwool that constitutes the core of sandwich panels.

Tabla 5 / Table 5

Valores medios de GF y ft en los paneles sándwich según la orientación de las probetas.

Mean values of GF $y$ ft of the sandwich panels depending on the specimen orientation.

\begin{tabular}{|c|c|c|c|}
\hline \multirow{2}{*}{$\begin{array}{c}\text { Tipo / Type } \\
\text { e-E-e }\end{array}$} & Sentido / Orientation & $G_{F}(\mathbf{N} / \mathbf{m})$ & $\boldsymbol{f}_{\boldsymbol{t}}(\mathrm{MPa})$ \\
\cline { 3 - 4 } & & Media $(\boldsymbol{\sigma}) / \mathbf{M e a n}(\boldsymbol{\sigma})$ & Media $(\boldsymbol{\sigma}) / \mathbf{M e a n}(\boldsymbol{\sigma})$ \\
\hline \multirow{2}{*}{$10-50-10$} & Longitudinal & $437(80.01)$ & $1.08(0.19)$ \\
\cline { 2 - 4 } & Transvesal & $326.56(28.42)$ & $1.23(0.07)$ \\
\hline \multirow{2}{*}{$12-60-12$} & Longitudinal & $548.15(118.31)$ & $1.01(0.09)$ \\
\cline { 2 - 4 } & Transvesal & $612.16(300.13)$ & $1.06(0.07)$ \\
\hline
\end{tabular}

e = espesor de la placa de yeso laminado $(\mathrm{mm}) /$ thickness of plasterboard surface $(\mathrm{mm})$.

$\mathrm{E}=$ espesor de la lana de roca $(\mathrm{mm}) /$ thickness of the rock-wool core $(\mathrm{mm})$.

$G_{F}$ : energía de fractura / specific fracture energy.

$f_{t}$ : resistencia a tracción / tensile strength.

E: módulo de elasticidad / Young's modulus. 
Tabla 6 / Table 6

Valores medios de $\mathrm{E}$ de la lana de roca según la orientación de las probetas.

Mean values of $E$ of the rock wool depending on the specimen orientation.

\begin{tabular}{|c|c|c|c|}
\hline \multirow{2}{*}{$\begin{array}{c}\text { Tipo / Type } \\
\text { e-E-e }\end{array}$} & Sentido / Orientation & \multicolumn{2}{|c|}{$E(\mathrm{MPa})$} \\
\cline { 2 - 4 } & & Longitudinal & 98.63 \\
\cline { 2 - 4 } & Transvesal & 26.63 \\
\cline { 2 - 4 }
\end{tabular}

$e=$ espesor de la placa de yeso laminado $(\mathrm{mm}) /$ Thickness of plasterboard surface $(\mathrm{mm})$

$\mathrm{E}=$ espesor de la lana de roca $(\mathrm{mm}) /$ Thickness of the rock-wool core $(\mathrm{mm})$.

A)

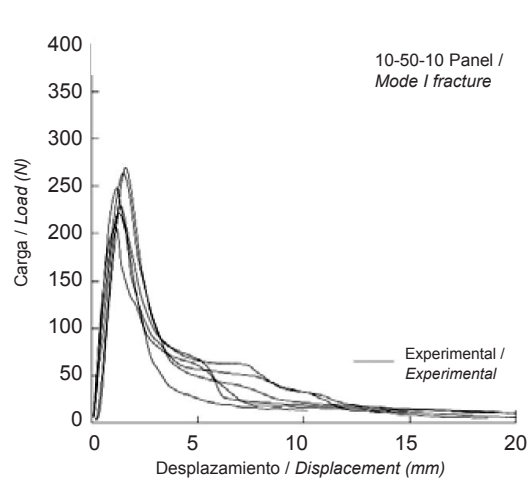

C)

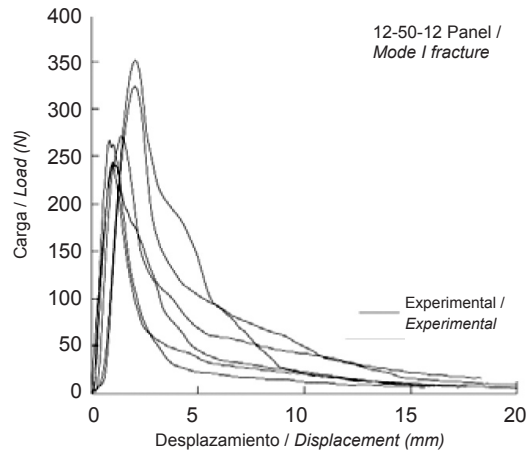

E)

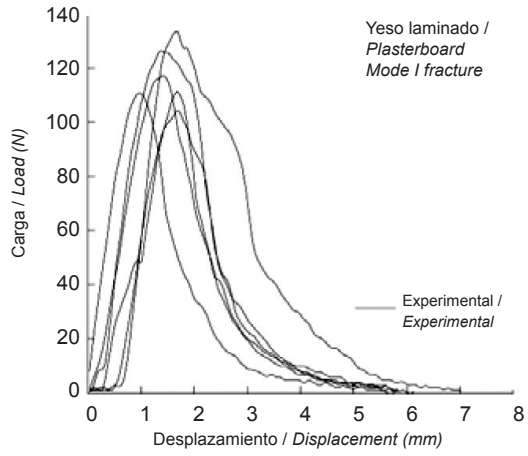

B)

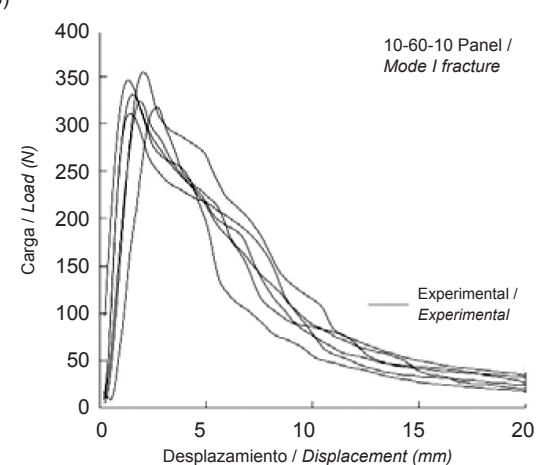

D)

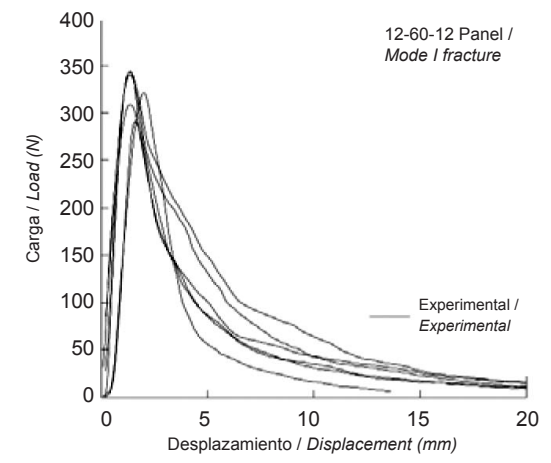

F)

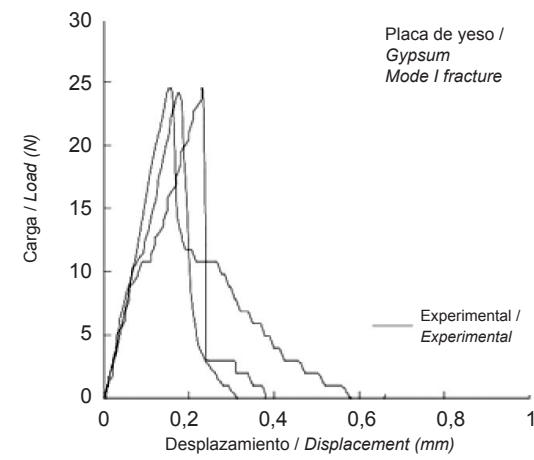

Figura 8. Resultados experimentales de los ensayos de fractura de los paneles sándwich de yeso laminado y lana de roca: a) panel $10-50-10$, b) panel 10-60-10, c) panel 12-50-12, d) panel 12-60-12, d) yeso laminado y e) placa de yeso.

Figure 8. Fracture experimental results of sandwich panel with plasterboard surfaces and rock wool core: a) panel 10-50-10, b) panel 10-60-10, c) panel 12-50-12, c) panel 12-60-12, d) plasterboard and e) gypsum. 


\section{MODELO DE CÁLCULO}

Con objeto de disponer de una herramienta que permita simular el comportamiento en rotura de los paneles sándwich bajo solicitaciones de tracción y cortante, en este trabajo se emplea un procedimiento de cálculo numérico basado en la fisura cohesiva.

El modelo se caracteriza por una curva tensión-apertura grieta con ablandamiento, que recibe el nombre de función de ablandamiento, y que es una propiedad del material. La función de ablandamiento, $\sigma=f(\omega)$, relaciona la tensión entre las caras de la grieta, $\sigma$, y la apertura de grieta, $\omega$. Cuando la apertura es en modo I, la tensión transferida es normal a las caras de la grieta. Los dos ingredientes fundamentales de la función de ablandamiento son la resistencia a tracción del material, $f_{t}$ y la energía específica de fractura, $G_{F}$, que coincide con el área bajo la función de ablandamiento y es la energía necesaria para romper completamente una superficie unidad de material cohesivo. Este modelo fue introducido a principios de los sesenta por Barenblatt (14) y Dugdale (15), siendo aplicado al hormigón por Hillerborg, Modéer y Petersson a principios de los setenta (16). Desde entonces se aplica con éxito al estudio de la fractura de materiales cuasi frágiles.

En este trabajo se ha adoptado un procedimiento numérico basado en la incorporación de la fisura cohesiva a un elemento finito con fisura embebida (5-7). El modelo se basa en la aproximación de la discontinuidad fuerte (17). El procedimiento se ha desarrollado para la simulación de fractura en modo mixto de hormigones y morteros (18) y materiales anisótropos como la fábrica de ladrillo (6).

Dado que el procedimiento se ha presentado con detalle previamente por los autores, en este trabajo se hace una breve descripción del mismo, y se remite al lector a las ref. $(5-7,18)$ para sus detalles.

Se considera un elemento finito como el mostrado en la Figura 9, con una grieta recta embebida. El elemento se puede separar en sub-dominios, separados por el desplazamiento $\overline{\mathbf{w}}$.

De acuerdo con la teoría de la discontinuidad fuerte (véase (17), por ejemplo), el campo de desplazamientos en el interior del elemento se puede expresar [1]:

\section{NUMERICAL MODEL}

In order to provide a numerical tool to simulate the fracture behaviour of sandwich panels of plasterboard and rockwool under tensile and shear, a numerical procedure based on the cohesive crack model is used.

This model is characterised by the softening function, $\sigma=f(\omega)$, which is a material property, and relates the stress transmitted between the crack faces, $\sigma$, and the crack opening, $\omega$. When the opening is in mode $I$, the stress is normal to the faces of the crack. The two basic ingredients of the softening function are the tensile strength of the material, $f_{t}$ and the specific fracture energy, $G_{F}$, which coincides with the area under the softening function and is the energy required to break completely a unit area of a cohesive material. This model was proposed in the early 1960s by Barenblatt (14) and Dugdale (15) and applied to concrete by Hillerborg, Petersson Modeer in the early 1970s (16). Since then the cohesive crack has been applied to the study of the fracture behaviour of quasi-brittle materials.

This work adopts a numerical procedure based on the incorporation of a cohesive crack in a finite element with an embedded crack (5-7). The model is based on the strong discontinuity approach (17). The procedure has been developed for the simulation of mixed-mode fracture of concrete and mortar (18) and later extended to anisotropic materials such as brickwork masonry (6).

Since the procedure has been presented in detail previously by the authors, this paper provides a brief description. For further details, the reader is referred to ref. $(5-7,18)$.

Consider a finite element as the one shown in Figure 9, with a straight crack embedded in it. The crack splits the element in two subdomains, separated by the displacement jump across the crack $\overline{\mathbf{w}}$.

According to the theory of strong discontinuity (e.g. (17)), the approximated displacement field within the element can be expressed as [1]:

$$
\boldsymbol{u}(x)=\sum_{(A)} N_{I}(x) \boldsymbol{u}^{I}+\left[H(x)-N^{+}(x)\right] \boldsymbol{w}
$$


donde $N_{I}(x)$ es la función de forma tradicional para el nodo $I$, $\boldsymbol{u}^{\mathrm{I}}$ es el desplazamiento nodal y $H(x)$ la función escalón de Heaviside que cambia de valor a cada lado de la grieta. Además, [2]. where $N_{I}(x)$ is the traditional shape function for node $I$, $\boldsymbol{u}^{\mathrm{I}}$ is the corresponding nodal displacement, and $H(x)$ is the Heaviside jump function across the crack plane, [2]. Furthermore,

$$
N^{+}(x)=\sum_{\left(I \in A^{+}\right)} N_{I}(x)
$$

El tensor de deformaciones se obtiene a partir del campo de desplazamientos continuo más la función $\delta$ de Dirac en la línea de la grieta. La parte continua de la deformación está dada por [3]:
The strain tensor is obtained from the continuous part of the displacement field plus Dirac's $\delta$ function on the crack line. The continuous part of the displacement is given by [3]:

$$
\boldsymbol{\varepsilon}^{c}(x)=\boldsymbol{\varepsilon}^{a}(x)-\left[\boldsymbol{b}^{+}(x) \otimes \boldsymbol{w}\right]^{S}
$$

donde $\boldsymbol{\varepsilon}^{\boldsymbol{a}}$ (tensor de deformación aparente) y $\boldsymbol{b}^{+}$se obtienen del siguiente modo [4]: where $\boldsymbol{\varepsilon}^{\boldsymbol{a}}$ (the apparent strain tensor) and $\boldsymbol{b}^{+}$are given by [4]:

$$
\begin{array}{r}
\boldsymbol{\varepsilon}^{a}(x)=\sum_{(A)}\left[\boldsymbol{b}_{I}(x) \otimes \boldsymbol{u}^{I}\right]^{S} \\
\boldsymbol{b}^{+}(x)=\sum_{\left(A^{+}\right)} \boldsymbol{b}_{I}(x)
\end{array}
$$

siendo $\boldsymbol{b}_{I}(\mathrm{x})=\operatorname{grad} N_{I}(x)$ y el superíndice $\mathrm{S}$ indica la parte simétrica del tensor.

En ese trabajo, se adopta un modelo de fuerzas centrales, según el cual el vector de tensiones $\overline{\mathbf{t}}$ que actúa sobre las caras de la fisura cohesiva, es paralelo al desplazamiento relativo $\overline{\mathbf{w}}$ de los labios de la grieta. La fisura cohesiva queda así caracterizada por la curva de ablandamiento que relaciona el módulo de $\overline{\mathbf{t}}$ con el de $\overline{\mathbf{w}}$, tal y como se esquematiza en la Figura 10. El modelo contempla la posible descarga del material [5]: with $\boldsymbol{b}_{I}(\mathrm{x})=$ grad $N_{I}(x)$ and the superscript $S$ indicates the symmetric part of the tensor.

In this work a central forces model is adopted, according to which the traction vector, $\overline{\mathbf{t}}$, transmitted across the crack faces is parallel to the crack displacement vector, $\overline{\mathbf{w}}$. The cohesive crack is thus characterised by the softening curve that relates the magnitude of $\overline{\mathbf{t}}$ with the magnitude of $\overline{\mathbf{w}}$, as shown in Figure 10. For monotonic loading in which the magnitude of the crack opening vector $|w|$ is never decreasing, the relationship reads [5]:

$$
\mathbf{t}=\frac{f(\tilde{W})}{\tilde{W}} \mathbf{w} \operatorname{con} \tilde{W}=\max (|\mathbf{w}|)
$$

donde $f(w)$ es la función de ablandamiento (Figura 10) y $\bar{W}$ es la apertura de grieta equivalente, definida como el máximo histórico del módulo del vector desplazamiento.

El material fuera de la grieta se asume como elástico lineal. El tensor de tensiones se expresa [6], a partir de las ecuaciones [3] y [5]: where $f(w)$ is the softening function (Figure 10) and $\overline{\mathrm{w}}$ is the equivalent crack opening, defined as the historical maximum of the magnitude of the crack displacement.

The material outside the crack is assumed as linear elastic. The stress tensor is given [6], from equations [3] and [5], by:

$$
\frac{f(\tilde{W})}{\tilde{W}} \mathbf{W}=\mathbf{E}:\left[\varepsilon^{a}-\left(\mathbf{b}^{+} \otimes \mathbf{w}^{s}\right)\right] \cdot \mathbf{n}
$$

Desarrollando la expresión previa se alcanza [7]:

By developing the previous expression the following is obtained [7]:

$$
\left[\frac{f(\tilde{W})}{\tilde{W}} \mathbf{1}+\mathbf{n} \cdot \mathbf{E} \cdot \mathbf{b}^{+}\right] \cdot \mathbf{W}=\left[\mathbf{E}: \varepsilon^{a}\right] \cdot \mathbf{n}
$$




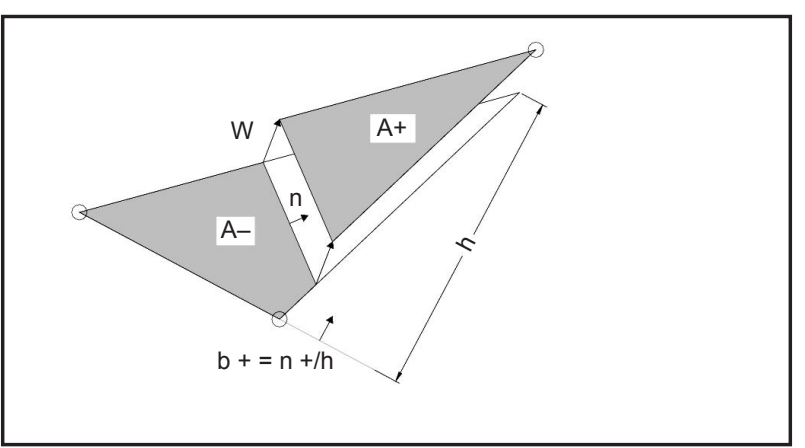

Figura 9. Elemento finito CST con fisura embebida. Figure 10. CST finite element with an embedded crack.
Esta ecuación se resuelve para $\overline{\mathbf{w}}$ con el método de Newton Raphson, a partir de los desplazamientos nodales (así como $\boldsymbol{\varepsilon}^{\boldsymbol{a}}$ ), una vez que se ha formado la grieta y los vectores $\boldsymbol{n}$ y $\boldsymbol{b}^{+}$son conocidos.

Con el fin de evitar el bloqueo de la grieta en su crecimiento, se acepta cierto grado de adaptabilidad en la dirección de la grieta dentro del elemento finito mientras la grieta tiene una apertura pequeña. Esta adaptabilidad de la dirección de la grieta responde a las variaciones de la dirección de la tensión principal mayor cuando la grieta apenas se ha abierto. El valor umbral que limita la adaptabilidad está relacionado con los parámetros de ablandamiento del material. En este trabajo se adopta un valor de 0,1-0,2 $G_{F} / f_{t}$ empleado satisfactoriamente en trabajos previos $(5,6,18)$. Superado este umbral se considera la grieta consolidada.

El procedimiento presentado se ha introducido en el programa comercial de elementos finitos ABAQUS, a través de una subrutina de usuario para material.

\section{REPRODUCCIÓN DE LOS RESULTADOS EXPERIMENTALES}

El modelo presentado se ha empleado para reproducir los resultados experimentales de fractura de las probetas ensayadas, tanto de fractura en modo I como fractura en modo mixto. El modelo emplea los parámetros medidos experimentalmente y presentados en las Tablas 3 y 4 . La Figura 11 muestra una malla de elementos finitos deformada correspondiente a la simulación de rotura en modo mixto de un panel sándwich de yeso laminado y lana de roca.

La Figura 12 compara los resultados del modelo de cálculo con los obtenidos experimentalmente para los ensayos de fractura en modo I de los cuatro tipos de panel, de la placa de yeso (sin papel) y del yeso laminado.

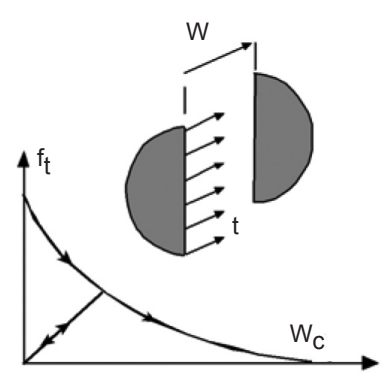

Figura 10. Esquema de la curva de ablandamiento con rama de descarga, basado en modelo de fuerzas centrales.

Figure 10. Sketch of the softening curve, with unloading branch, and central-foreces model for the cohesive crack model.

This equation is solved for $\overline{\mathbf{w}}$ using the Newton-Raphson method given the nodal displacements (and so $\boldsymbol{\varepsilon}^{\mathrm{a}}$ ), once the crack is formed and thus $\boldsymbol{n}$ and $\boldsymbol{b}^{+}$are also known.

In order to avoid the crack locking during its growth, the procedure permits a certain amount of adaptability in the direction of the crack within the finite element while the crack opening is small. This adaptability of the direction of the crack is due to variations in the first principal stress direction when the crack has just opened. Threshold values of the crack adaptability must be related to the softening properties of the material. In this paper a value of $0.1-0.2 G_{F} / f_{t}$ is adopted, one that has been used in previous works $(5,6,18)$. Once the threshold is reached, the crack direction is consolidated.

The described model has been introduced in the commercial finite element code ABAQUS, by means of a user material subroutine.

\section{NUMERICAL PREDICTION OF THE EXPERIEMENTAL RESULTS}

The described model is used to reproduce the experimental results of the two types of fracture tests carried out on sandwich panel specimens: mode I fracture test and mixed mode fracture test. The model uses the experimentally measured parameters shown in Tables 3 and 4. Figure 11 shows a deformed finite element mesh corresponding to the numerical simulation of the mixed mode fracture of a sandwich panel of plasterboard and rockwool specimen.

Figure 12 compares the numerical prediction of the model with the experimental results of the mode I fracture tests for the four types of sandwich panel, the plasterboard (without paper) and the laminated plasterboard specimens. 


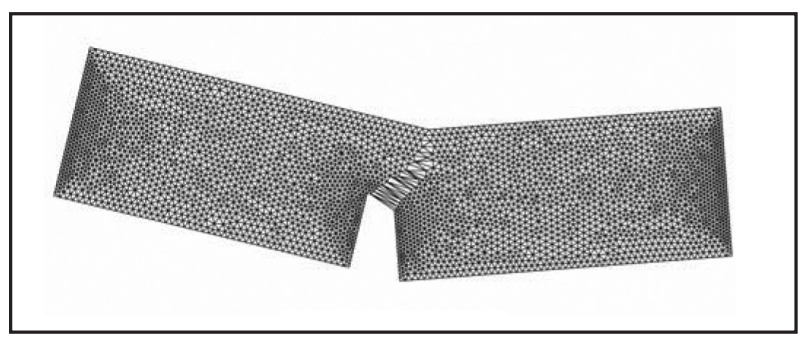

Figura 11. Malla de elementos finitos deformada correspondiente a una probeta de panel sándwich en un ensayo de fractura en modo mixto.

Figure 11. Finite element deformed mesh of a sandwich panel specimen under mixed mode loading conditions.

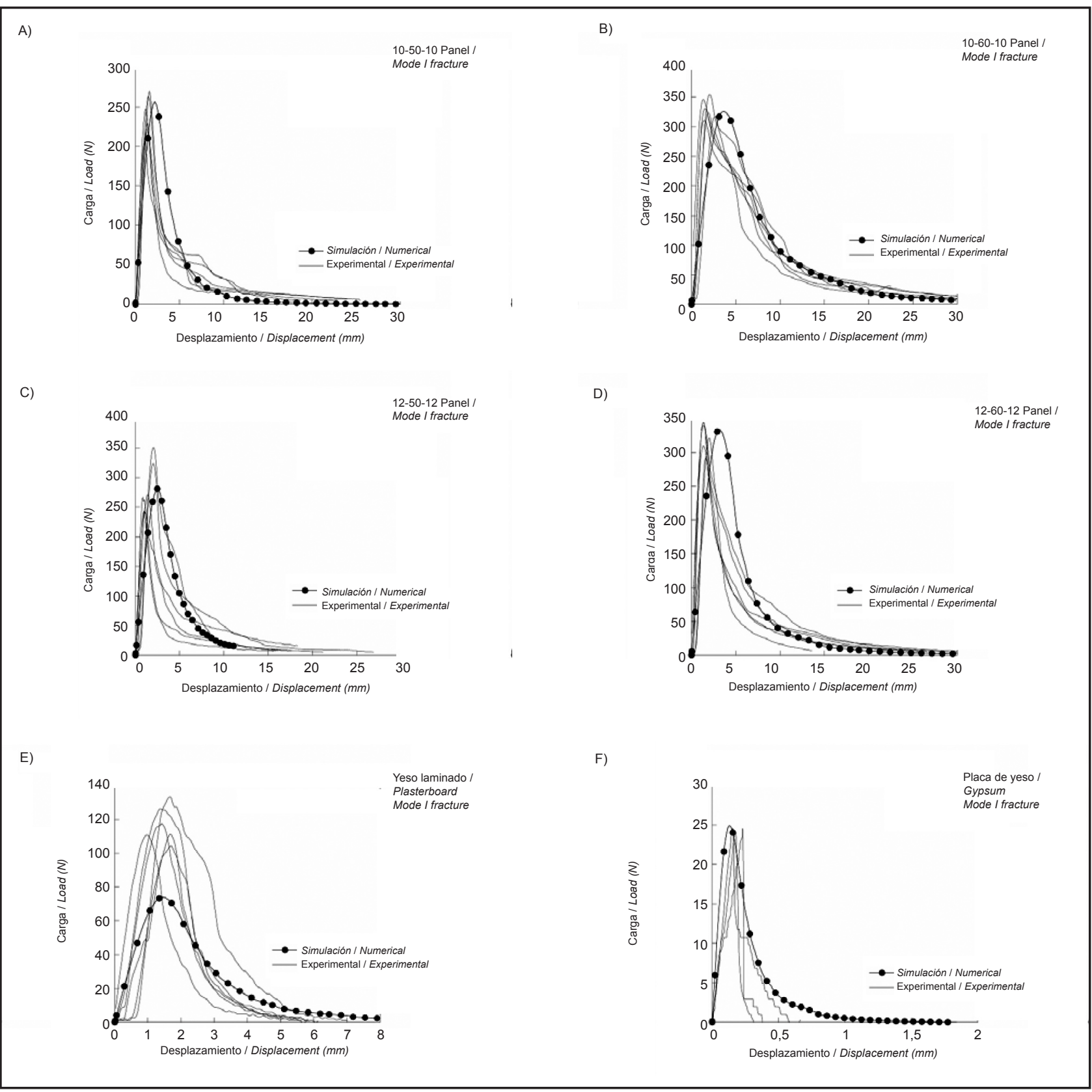

Figura 12. Resultados experimentales y predicción numérica en los ensayos de fractura en modo I para los paneles sándwich: a) panel 10-50-10, b) panel 10-60-10, c) panel 12-50-12, d) panel 12-60-12, e) yeso laminado y f) placa de yeso. Figure 12. Fracture experimental results and numerical prediction of the mode I fracture tests: a) panel 10-50-10, b) panel 10-60-10, c) panel 12-50-12, d) panel 12-60-12, e) plasterboard and f) gypsum. 


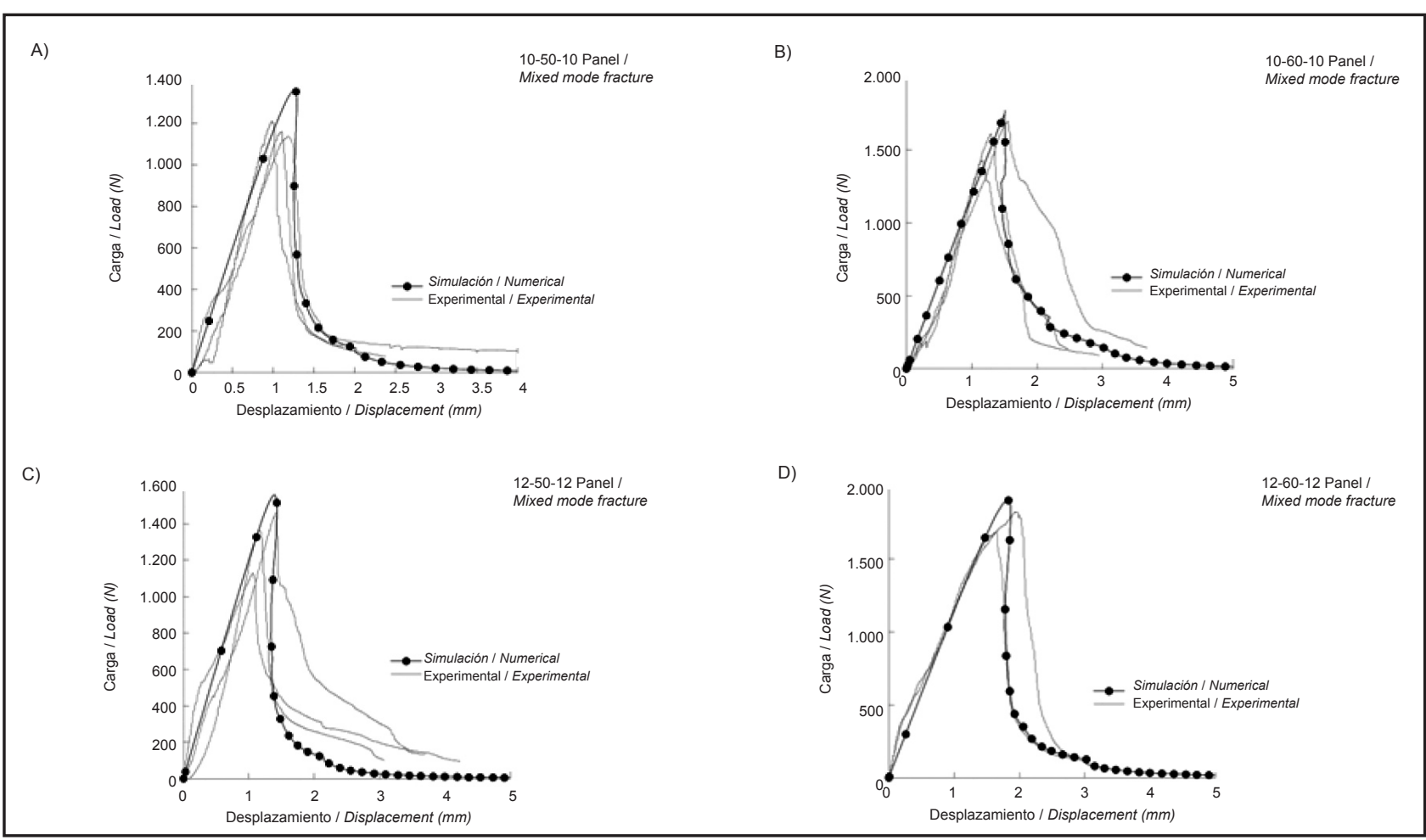

Figura 13. Resultados experimentales y predicción numérica en los ensayos de fractura en modo mixto para los paneles sándwich: a) panel 10-50-10, b) panel 10-60-10, c) panel 12-50-12 y d) panel 12-60-12.

Figure 13. Fracture experimental results and numerical prediction of the mixed mode fracture tests: a) panel 10-50-10, b) panel 10-60-10, c) panel 12-50-12 and d) panel 12-60-12.

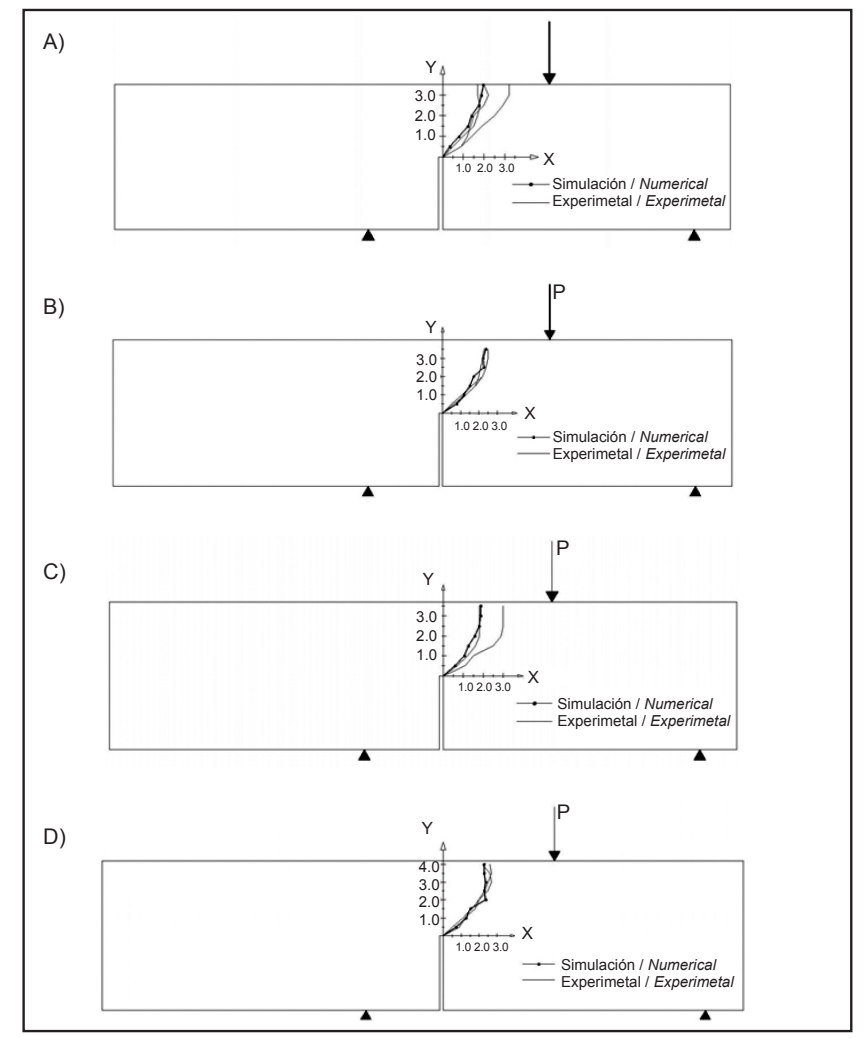

Figura 14. Trayectorias experimentales y predicción numérica en los ensayos de fractura en modo mixto para los paneles sándwich: a) panel 10-50-10, b) panel 10-60-10, c) panel $12-50-12$ y d) panel $12-60-12$.

Figure 14. Experimental records and numerical prediction of the mixed mode crack paths: a) panel 10-50-10, b) panel 10-60-10, c) panel 12-50-12 and d) panel 12-60-12. 
La Figura 13 compara los resultados del modelo de cálculo con los experimentales para los ensayos de fractura en modo mixto de los cuatro tipos de panel.

La Figura 14 compara las trayectorias de las grietas obtenidas por el modelo de cálculo y las experimentales para los ensayos de fractura en modo mixto de los cuatro tipos de panel.

Como se puede ver el modelo reproduce adecuadamente los resultados experimentales de fractura, tanto en modo I como en modo mixto.

\section{DISCUSIÓN}

A partir de las Tablas 5 y 6 se puede ver que ni el panel ni la lana de roca son transversalmente isótropos, variando las propiedades mecánicas hasta un $25 \%$ de media en función de la dirección de estudio. Esto era de esperar por el sistema de fabricación de la lana de roca, en el que las fibras se depositan de manera aleatoria, pero siempre con una cierta orientación preferente hacia el sentido de fabricación.

En lo que respecta a los paneles de yeso laminado y lana de roca, se observa en primer lugar, que la energía de fractura está muy condicionada por el espesor de la lana de roca, y no tanto por el espesor de la placa de yeso laminado. Esto se debe a la composición de la lana de roca, formada por fibras aglomeradas, que son capaces de generar un gran número de micro fisuras durante el proceso de rotura, disipando energía por rozamiento entre las fibras, y aumentando la energía necesaria para el avance de la fisura. Es por ello que se obtiene una elevada energía específica de fractura.

Un mecanismo parecido se presenta en el caso de la placa de yeso laminado, donde los valores de la energía de fractura del yeso laminado son dos órdenes de magnitud superiores al yeso. En este caso el papel ejerce el rol de la lana de roca en el panel, pues sus fibras de celulosa producen el mismo mecanismo a la hora de producirse la fractura.

Respecto al modelo de cálculo conviene resaltar que emplea parámetros del material medidos experimentalmente mediante ensayos normalizados. Estos ensayos son independientes y previos a los ensayos simulados. Este aspecto permite indicar que se trata de un modelo predictivo y no postdictivo.
Figure 13 compares the numerical prediction of the model with the experimental results of the mixed mode fracture tests for the four types of sandwich panel specimens.

Figure 14 compares the crack trajectories obtained by the numerical model and the experimental ones for the mixed mode fracture tests of the four types of panel.

The model adequately reproduces the experimental results of mode $I$ and mixed mode fracture tests.

\section{DISCUSSION}

From Tables 5 and 6 it can be seen that neither the panel nor the rockwool are transversely isotropic. Depending on the direction of study, their mechanical properties vary up to $25 \%$ on average. This was expected, due to the manufacturing system of the rockwool in which the fibres are deposited randomly, but always with a certain preferred orientation to the direction of manufacture.

In the case of the sandwich panels of plasterboard and rockwool, it can be observed that the fracture energy is strongly influenced by the thickness of the rockwool, and not by the thickness of the laminated plasterboard. This is because the composition of the rockwool, formed by agglomerated fibres which are capable of generating a large number of micro-cracks during the cracking process, dissipating energy by friction between the fibres, and increasing the necessary energy for the advancement of the crack. This is the reason for a high specific energy of fracture being obtained.

A similar mechanism occurs in the case of the laminated plasterboard, in which the values of the fracture energy are two orders of magnitude higher than in the gypsum. In this case the paper plays the role of the rockwool in the sandwich panel, as its cellulose fibres have a similar behaviour when the fracture occurs.

Regarding the proposed model it is worth highlighting that it uses material parameters experimentally measured by standardised tests. Such tests are independent and previous to the simulated tests. This point permits qualification of the model as a predictive one. 


\section{COMENTARIOS FINALES Y CONCLUSIONES}

Este trabajo analiza el comportamiento en rotura de paneles sándwich de yeso laminado con alma de lana de roca dentro de su plano. Se han estudiado los paneles en su conjunto y cada uno de sus componentes por separado. Los resultados obtenidos son novedosos y aportan datos sobre las propiedades mecánicas, particularmente de fractura, hasta ahora inexistentes. Estos datos permiten una mejor caracterización de este material y facilitan el uso de modelos de cálculo para estudiar su comportamiento en rotura. Especialmente su comportamiento en edificación como partición interior vertical sometida a deformaciones de forjados y asientos diferenciales.

Los resultados obtenidos de la campaña experimental han mostrado la gran influencia que tiene en la energía de fractura el alma de lana de roca, que si bien no aporta mayor resistencia a tracción aumenta de forma considerable la energía de fractura. Análogo razonamiento se aplica al papel que recubre el yeso laminado cuando se compara su compartimento frente a la lámina de yeso sin papel. En ambos casos, la anisotropía de las fibras confiere comportamiento anisótropo al panel sándwich de yeso laminado con alma de lana de roca. Esta anisotropía conduce a valores de la energía de fractura que difieren en hasta un $25 \%$ según la dirección de ensayo.

El modelo de fisura cohesiva, implementado en elementos finitos con fisura embebida, constituye una buena aproximación del comportamiento en fractura de paneles sándwich de yeso y alma de lana de roca. Los resultados obtenidos indican que el uso de este tipo de modelos cohesivos para este material es muy prometedor. Desde el punto de vista práctico, el uso de modelos que empleen propiedades medidas mediante ensayos normalizados constituyen una herramienta útil para el estudio de la fisuración de los cerramientos interiores, la identificación de las causas y la posible limitación a las flechas y movimientos relativos entre forjados.

\section{AGRADECIMIENTOS}

Los autores desean agradecer al Ministerio de Economía y Competitividad las concesión de las ayudas DPI201124876 e IPT-42000-2010-31. Además agradecen a TEZNOCUBER S.A. el suministro de los paneles sándwich de yeso laminado y alma de lana de roca empleados en la investigación.

\section{FINAL COMMENTS AND CONCLUSIONS}

This work analyses the fracture behaviour of sandwich panels of plasterboard and the rockwool core within its plane. The panels are studied as a whole and each of the components separately. The results are innovative and provide data on the mechanical properties, particularly of fracture, until the time of writing inexistent. These data allow a better characterisation of this material and facilitate use of numerical models for studying their fracture behaviour. Of particular note is their behaviour in building vertical interior partitions under the deformation of floor slabs and differential settlement.

The experimental results show the high degree of influence that the fracture energy has on the core of rockwool which, although it does not provide greater tensile strength, increases the fracture energy significantly. Similar reasoning applies to the paper covering the plasterboard when comparing it with the plaster (plasterboard without board). In both cases, the anisotropy of the fibres gives anisotropic behaviour to sandwich panel of plasterboard plaster with core of rockwool. This anisotropy leads to values of the fracture energy that differ by up to $25 \%$, depending on the testing direction.

The cohesive crack model, implemented in finite element with an embedded crack, is a good approximation of the behaviour in fracture of sandwich panel of plasterboard plaster with a core of rockwool. The results obtained indicate that the use of this type of cohesive model for the material is highly promising. From a practical point of view, the use of models employing measured properties using standardised tests is a useful tool for the study of cracking of interior walls, identification of the causes and possible limitation to deflections and relative movements between slabs.

\section{ACKNOWLEDGEMENTS}

The authors gratefully acknowledge the financial support for the research provided by the Spanish Ministerio de Economía y Competitividad under grants IPT-420002010-3 and DPI2011-24876. In addition, they also thank TEZNOCUBER S.A. for the supply of plasterboard and rockwool sandwich panels used in this work. 


\section{BIBLIOGRAFÍA / BIBLIOGRAPHY}

(1) Comunicación oral del Departamento de Marketing, Placo, Grupo Saint Gobain. (Consulta realizada en 2011).

(2) Villanueva, L.; Lasheras, F.; del Río, M. y Hernández-Olivares, F.: "Modelo matemático del comportamiento mecánico en flexión del cartón-yeso", Inf. Constr, vol. 45, no 430, pp. 43-51, 1994. .http://dx.doi.org/10.3989/ic.1994.v45.1430.1141

(3) Ministerio de la Vivienda: "Código Técnico de la Edificación. Documento Básico HR: Protección Frente al Ruido". Madrid (2011).

(4) Ministerio de la Vivienda, CSIC. Instituto Eduardo Torroja: "Catálogo de elementos constructivos del Código Técnico de la Edificación". Madrid (2010).

(5) Sancho, J.M.; Planas, J.; Cendón, D.A.; Reyes, E.; Gálvez, J.C.: "An embedded crack model for finite element analysis of concrete fracture", Engineering Fracture Mechanics, 74 (1-2), pp. 75-86, 2007. http://dx.doi.org/10.1016/j.engfracmech.2006.01.015

(6) Reyes, E.; Gálvez, J.C.; Casati, M.J.; Cendón, D.A.; Sancho, J.M.; Planas, J.: "An embedded cohesive crack model for finite element analysis of brickwork masonry fracture". Engineering Fract. Mech 76, pp. 1930-1944, 2009.

(7) Reyes, E.; Casati, M.J.; Gálvez, J.C.: "Experimental scale model study of cracking in brick masonry under tensile and shear stress". Mater. Construcc., 58, 291, pp. 69-83, 2008.

(8) Río Merino, M. del Santa Cruz Astorqui, J.: "Finite element simulation to design constructive elements: An application to light gypsum plaster for partitions", Constr. and Build. Mater. 23, pp. 14-27, 2009. http://dx.doi.org/10.1016/j.conbuildmat.2007.12.009

(9) Telue, Y.; Mahendran, M.: "Behaviour of cold-formed steel wall frames lined with plasterboard", Journal of Constructional Steel Research 57, pp. 435-452, 2001. http://dx.doi.org/10.1016/S0143-974X(00)00024-9

(10) Restrepo, J.I.; Bersofsky, A.M.: "Performance characteristics of light gage steel stud partition walls", Thin-Walled Structures 49, pp. 317-324, 2011. http://dx.doi.org/10.1016/j.tws.2010.10.001

(11) Asociación Española de Normalización y Certificación, 'Norma UNE EN 520:2005. Placa de yeso laminado. Definiciones, especificaciones y métodos de ensayo". Madrid (2005).

(12) Asociación Española de Normalización y Certificación, "Norma UNE EN 13.162:2002 Lana de roca. Definiciones, especificaciones y métodos de ensayo". Madrid (2002).

(13) RILEM 50-FMC Committee Fracture Mechanics of Concrete. "Determination of the fracture energy of mortar and concrete by means of three-point bend tests on notched beams". Mater. Construct. vol. 18, pp. 285-290 (1986).

(14) Barenblatt, G.I.: "The mathematical theory of equilibrium of cracks in brittle fracture". Adv. Appl. Mech.; vol. 7, pp. 55-129 (1962).

(15) Dugdale, D.S.: "Yielding of steel sheet sheets containing slits". J. Mech. Phys, vol. 8, pp. 100-108 (1960).

(16) Hillerborg, A.; Modéer, M.; Petersson, P.E.: "Analysis of crack formation and crack growth in concrete by means of fracture mechanics and finite elements". Cement. Concret. Res., vol. 6, pp. 773-782 (1976).

(17) Simó, J.; Oliver, J.; Armero, F.;"An analysis strong discontinuities induced by strain softening in rate-independent inelastic solids". Comput. Mech.; 12:277-96 (1993). http://dx.doi.org/10.1007/BF00372173

(18) Sancho, J.M.; Planas, J.; Gálvez, J.C.; Reyes, E.; Cendón, D.A.: "An embedded cohesive crack model for finite element analysis of mixed mode fracture of concrete". Fatigue Fract. Engng. Mater. Struct. vol. 29, pp. 1056-1065. 2006. http://dx.doi.org/10.1111/j.14602695.2006.01076.x 